\title{
BLOOD LEAD, CADMIUM AND MERCURY AMONG CHILDREN FROM URBAN, INDUSTRIAL AND RURAL AREAS OF FEZ BOULEMANE REGION (MOROCCO): RELEVANT FACTORS AND EARLY RENAL EFFECTS
}

\section{JAWHAR LAAMECH ${ }^{1}$, ALFRED BERNARD ${ }^{2}$, XAVIER DUMONT ${ }^{2}$, BOUCHRA BENAZZOUZ ${ }^{3}$, and BADIAA LYOUSSI ${ }^{1}$}

\author{
${ }^{1}$ Faculty of Sciences DM, USMBA University, Fez, Morocco \\ Laboratory of Physiology, Pharmacology and Environmental Health \\ ${ }^{2}$ Université Catholique de Louvain, Brussels, Belgium \\ Unit of Industrial Toxicology and Occupational Medicine, Faculty of Medicine \\ ${ }^{3}$ Faculty of Sciences University of Ibn Tofail, Kenitra, Morocco \\ Laboratory of Genetic Neuroendocrinology and Biotechnology
}

\begin{abstract}
Objectives: To describe blood lead (Pb-B), cadmium (Cd-B) and mercury (Hg-B) levels in children living in urban, industrial and rural areas in Fez city (north of Morocco) and to identify the determinants and some renal effects of exposure. Material and Methods: The study was conducted from June 2007 to January 2008 in 209 school children (113 girls, 96 boys), aged 6-12 years, from urban, industrial and rural areas in Fez city. Interview and questionnaires data were obtained. Blood and urinary samples were analyzed. Results: The mean of blood lead levels $(\mathrm{Pb}-\mathrm{B})$ in our population was $55.53 \mu \mathrm{g} / \mathrm{l}$ (range: 7.5-231.1 $\mu \mathrm{g} / \mathrm{l}$ ). Children from the urban area had higher blood lead levels (BLLs) mean (82.36 $\mu \mathrm{g} / 1)$ than children from industrial and rural areas (48.23 and $35.99 \mu \mathrm{g} / \mathrm{l}$, respectively); with no significant difference between boys and girls. BLLs were associated with traffic intensity, passive smoking and infancy in the urban area. The mean of blood cadmium levels (BCLs) was $0.22 \mu \mathrm{g} / \mathrm{l}$ (range: $0.06-0.68 \mu \mathrm{g} / \mathrm{l}$ ), with no difference between various areas. Rural boys had higher BCLs mean than rural girls, but no gender influence was noticed in the other areas. BCLs were associated with the number of cigarettes smoked at children's homes. The blood mercury levels (BMLs) mean was $0.49 \mu \mathrm{g} / \mathrm{l}$ (range: 0.01-5.31 $\mu \mathrm{g} / \mathrm{l}$ ). The BMLs mean was higher in urban and industrial areas than in the rural area with no gender-related difference. BMLs were associated with amalgam fillings and infancy in the urban area. About $8 \%$ of the children had BLLs $\geq 100 \mu \mathrm{g} / \mathrm{l}$ particularly in the urban area, microalbuminuria and a decrease in height were noticed in girls from the inner city of Fez and that can be related to high BLLs $(89.45 \mu \mathrm{g} / \mathrm{l})$. Conclusions: There is a need to control and regulate potential sources of contamination by these trace elements in children; particularly for lead.
\end{abstract}

Key words:

Exposure, Trace elements, Biomonitoring, Children, Determinants, Renal effects

The article was supported by grants supplied from the European Union (Sixth Framework Programme; PHIME; FOOD-CT-2006-016253) and a long series of funding agencies in the participating countries. The paper reflects only the authors' views; the European Union is not liable for any use that may be made of the information. Grant manager: Skerfving Staffan, MD, PhD.

Received: January 25, 2014. Accepted: March 31, 2014.

Corresponding author: B. Lyoussi, Laboratory of Physiology, Pharmacology and Environmental Health, PO. BOX: 1796 Fez Atlas, Morocco (e-mail: lyoussi@gmail.com). 


\section{INTRODUCTION}

Heavy metal pollution has become a serious health concern in recent years. Lead $(\mathrm{Pb})$, cadmium $(\mathrm{Cd})$ and mercury $(\mathrm{Hg})$ are the most studied toxic heavy metals. Continuous exposure to low levels of these toxic trace elements may result in bioaccumulation and cause a wide variety of biological effects on human beings depending upon the level and the duration of exposure [1,2]. The margin is small between the level of exposure and toxic effects. Therefore, for risk assessment and management and for follow-up of time trends, there is a need for adequate information on exposure and health effects. For the toxic metals $\mathrm{Pb}, \mathrm{Cd}$ and $\mathrm{Hg}$, their concentrations in blood are relevant biomarkers of exposure, though the demands on analytical quality are high $[3,4]$.

The environmental situation in the city of Fez (north of Morocco; Figure 1) is very disturbing, especially since it is a big city with heavy traffic where lead is just limited, but still used in gasoline [5]. Fez city is also the 2nd most industrial city in Morocco (after Casablanca city), but the majority of industrial areas are located close to residential areas; as is the case of industrial area of Sidi Brahim that houses many polluting industries: mechanical, electrical, metallic, foundries, building materials, ceramics, glass, wool and leather [6]. These industries are usually highly charged with heavy metals and releasing particularly lead and cadmium [7,8].

The general population is exposed to $\mathrm{Pb}$ mainly from petrol, active or passive smoking, industrial emissions, paint and ceramics $[9,10]$. Cigarettes smoke is the main source of exposure to cadmium, although there are other such as contaminated water, foods enriched with this metal like shellfish, dairy products and meat (especially liver and kidneys), foods improperly stored in containers, which contain cadmium, and the inhalation of polluted air from foundries or incinerations [11]. Environmental exposure to mercury $(\mathrm{Hg})$ comes mainly from fish intake and dental amalgam fillings [4].

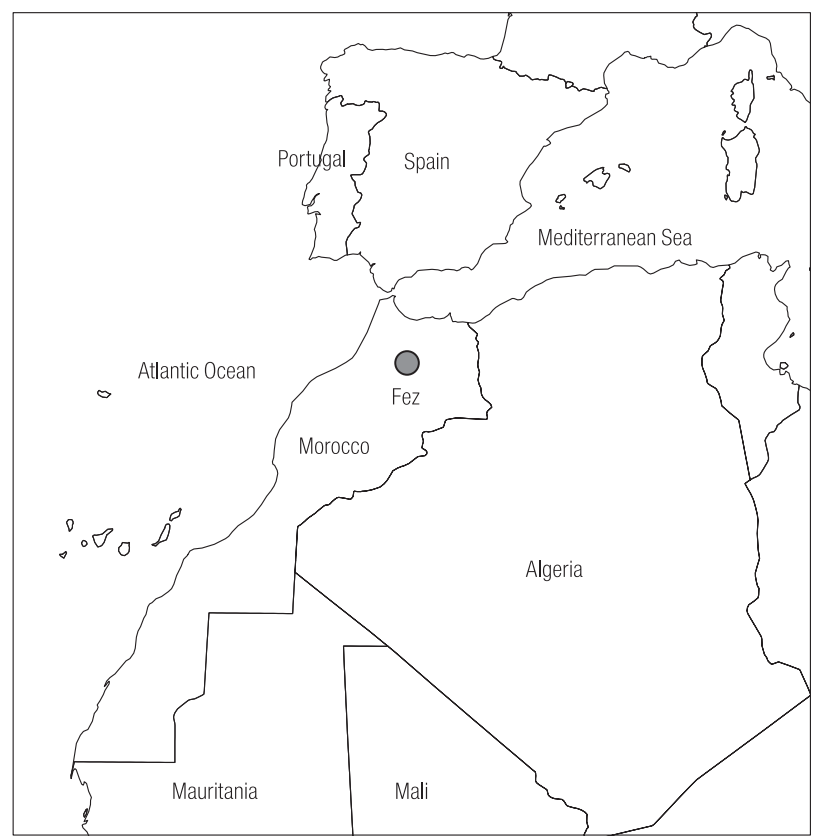

Fig. 1. City of Fez in the north of Morocco

The nephrotoxic effects of both acute and chronic exposure to heavy metals such as cadmium, lead and mercury are well known. However, so far few studies have concerned the actual impact of low environmental pollution exerted by these metals on the kidney, particularly in children who are considered a high-risk group as they absorb heavy metals more readily than adults and are particularly sensitive to them for biological and developmental reasons [12]. Early signs of renal dysfunction can be found even at low environmental levels of these heavy metals, consisting mainly in a decreased glomerular filtration rate (for lead) or in an increased urinary loss of tubular enzymes (for cadmium and mercury). These effects have mainly been described in adults, but certain reports have also shown them to occur in children [13-15]. The urinary markers chosen in our study were indicative of either the integrity of specific segments of the nephron such as the glomerular filter (urinary albumin) or the proximal tubule by evaluating low molecular weight proteinuria (urinary retinol bending protein: RBP); all adjusted for urinary creatinine $[16,17]$. 
Hence, we present here data on concentrations in blood of $\mathrm{Pb}(\mathrm{Pb}-\mathrm{B}), \mathrm{Cd}(\mathrm{Cd}-\mathrm{B})$ and $\mathrm{Hg}(\mathrm{Hg}-\mathrm{B})$, a number of their determinants, and some sensitive biomarkers of their early renal effects; in children (6-12 years) from 3 areas in Fez city (Morocco): urban, industrial and rural. Strict control of analytical quality was performed and we believe this is the first study concerning the blood concentrations of $\mathrm{Pb}, \mathrm{Cd}$ and $\mathrm{Hg}$, at environmental level of exposure in Moroccan children with evaluation of determinants and some renal effects of this exposure.

\section{MATERIAL AND METHODS}

\section{Study areas and subjects}

The study was conducted from June 2007 to January 2008. Participants were selected randomly and a total of 209 school children (113 girls, 96 boys), sex ratio G/B: 1.17, aged 6-12 years, in three primary schools located in the Fez city (north of Morocco; Figure 1: the map) were studied. The 3 schools were chosen in 3 areas of Fez city: urban (inner city in Bab Fettouh area), industrial (Sidi Brahim area) and rural (Laanoucer area). Since all children lived very close to their schools, the urban area is represented in this study by the school of Bab Fettouh (in the inner city) and children from homes located around it (less than $5 \mathrm{~m}$ away from the main street, but more than $5 \mathrm{~km}$ away from industrial plants), while the industrial area is represented by the Sidi Brahim school and homes located around it (about $1 \mathrm{~km}$ away from the main street, but about $500 \mathrm{~m}$ away from the industrial activities).

The school of Laanoucer and homes located around it represented the rural area (located about $40 \mathrm{~km}$ away from Fez city, more than $5 \mathrm{~km}$ away from the main street and with no industrial activity). Therefore, the rural area is considered as the control area in terms of trace elements environmental exposure. The exclusion criteria were obesity, diabetes, puberty and living far from every school. Only one child per household could take part in the study.

\section{Questionnaire}

A questionnaire containing a written description of the study was sent to 500 families. Two hundred and fifty of them agreed to give blood samples, and we were able to take samples from 209 children (113 girls, 96 boys). Firstly, a pediatrician performed an examination of the child health state, and then a nurse measured arterial blood pressure, glycemia and anthropometric data before qualifying a child to the study.

Most of the questions had predefined answers (categorical), while some were numerical (number of meals, amalgams, etc.). Information on demographic and socioeconomic characteristics of the families and individual factors of potential concern for $\mathrm{Pb}, \mathrm{Cd}$ and $\mathrm{Hg}$ exposure was obtained through 2 sources: a questionnaire addressed to the parents, and an interview/examination of the child. From the parents' questionnaire, the following information was obtained:

- parental education level (basic, middle, high), parental occupational exposure to the studied trace elements ( $\mathrm{Pb}, \mathrm{Cd}, \mathrm{Hg}$ : yes/no), parental smoking at home (yes/no),

- other people smoking at home (yes/no),

- number of cigarettes smoked per day (0 vs. 1-4 vs. $\geq 5$ cigarettes),

- child infancy in urban or rural environment,

- number of years of living in this area, source of water and heating and lead-based pipes,

- house built before 1970 (use of lead in painting: yes/no),

- closeness of house to incineration ( $\leq 100 \mathrm{~m}$ : yes/no),

- child's intake of offal (less than one vs. one or more meals per month),

- fish (fresh, frozen or canned: 0, at least once every 2 weeks, once a week, and $\geq 2$ meals per week), and shellfish (less than 1 vs. 1 or more meals per month),

- regular consumption of garden vegetables.

The information obtained at the interview/examination is listed below: 
- visits to a dentist during the last month (yes/no),

- number of amalgam fillings,

- daily use of chewing gum on amalgams (yes/no),

- child's attempts to smoke.

\section{Blood and urinary sampling}

Biological samples were collected with the written permission of either a children's parent or the person responsible for them. A nurse took venous blood samples from the arm after cleaning it with an ethanol swab. We used plastic $4 \mathrm{ml}$ lithium heparin tubes for sampling (GreinerBio One GmbH, Frickenhausen, Germany). The levels of all three metals in these tubes were below $0.03 \mu \mathrm{g} / \mathrm{l}$ at leaching tests with $4 \mathrm{ml}$ of $2 \%$ nitric acid. All samples were stored in a freezer at $-20^{\circ} \mathrm{C}$ directly after sampling, transported to the laboratory of Lund (Sweden) by means of DHL Society on dry ice and again stored at $-20^{\circ} \mathrm{C}$ until trace elements analysis.

After blood sampling, every child gave a urinary sample. These samples were directly transported to the laboratory of UCL-Louvain (Brussels) by means of DHL Society on dry ice and again stored at $-20^{\circ} \mathrm{C}$ until analysis of urinary protein: albumin (Alb-U), retinol-binding protein (RBP-U) and creatinine (Creat-U). Due to the small volumes of some samples, not all biological parameters could be determined in all subjects. The exact numbers of samples that could be analyzed are indicated in the tables.

\section{Chemical analyses}

All trace elements analyses were carried out on whole blood within one year of collection at the Department of Occupational and Environmental Medicine, University Hospital, Lund, Sweden. B-Pb and B-Cd were determined by inductively coupled plasma mass spectrometry (ICPMS; Thermo X7, Thermo Elemental, Winsford, UK). A sample volume of $250 \mu$ l was diluted 10 times with an alkaline solution [18].
Using this solution as a carrier/rinsing fluid, the samples were introduced in a segment-flow mode and analyzed in peak-jumping mode, 75 sweeps and 1 point per peak, $30 \mathrm{~ms}$ dwell time for $114 \mathrm{Cd}$ and $118 \mathrm{Sn}, 20 \mathrm{~ms}$ for 206, 207, $208 \mathrm{~Pb}$ (summed) and $10 \mathrm{~ms}$ for the internal standards $115 \mathrm{In}, 205 \mathrm{Tl}$ and $209 \mathrm{Bi}$. Interference corrections were made for $114 \mathrm{Cd}$ for the spectral overlap of $\mathrm{Sn}$. The detection limits for $\mathrm{Cd}$ and $\mathrm{Pb}$, calculated as 3 times the standard deviation (SD) of the blank (based on all blanks in one analytical batch), varied slightly from day to day and equaled on average $0.01 \mu \mathrm{g} / \mathrm{l}$ (range: $0.01-$ $0.04 \mu \mathrm{g} / \mathrm{l}$ ) for $\mathrm{Cd}$ and $0.06 \mu \mathrm{g} / \mathrm{l}$ (range: $0.05-0.10 \mu \mathrm{g} / \mathrm{l}$ ) for $\mathrm{Pb}$.

All samples were prepared in duplicate, and the method imprecision values (calculated as the coefficient of variation for all duplicate preparations measurements) were for $\mathrm{Cd}=9.3 \%$ and $\mathrm{Pb}=6.8 \%$, with both preparations and analyses made pair wise. The analytical accuracy was checked against the reference material: for Seronom trace elements whole blood (Lot. MR4206, SERO AS, Billingstad, Norway), the results obtained were as follows: for $\mathrm{Cd}=0.61 \pm 0.03 \mu \mathrm{g} / \mathrm{l}$ (mean (M) \pm standard deviation (SD); $\mathrm{N}=51$; recommended: $0.68-0.80 \mu \mathrm{g} / \mathrm{l})$, and for $\mathrm{Pb}=26.7 \pm 1 \mu \mathrm{g} / \mathrm{l}(\mathrm{N}=21$; recommended 26.2-29 $\mu \mathrm{g} / \mathrm{l})$.

For human blood reference samples from the Centre de Toxicologie du Quebec, International Comparison Program, Quebec, Canada, the obtained value for $\mathrm{Cd}$ (Lot C0515) was $0.76 \pm 0.14 \mu \mathrm{g} / \mathrm{l}(\mathrm{N}=51$; recommended $0.79 \pm 0.23 \mu \mathrm{g} / \mathrm{l})$ and for $\mathrm{Pb}$ (Lot L0608) it was $31.8 \pm 1.1 \mu \mathrm{g} / \mathrm{l}$ $(\mathrm{N}=21$; recommended: $31.1 \pm 4.7 \mu \mathrm{g} / \mathrm{l})$. Hg-B was determined in acid-digested samples by cold vapor atomic fluorescence spectrophotometry [19]. The detection limit was on average $0.07 \mu \mathrm{g} / \mathrm{l}$ (range: $0.03-0.13 \mu \mathrm{g} / \mathrm{l}$ ). The method imprecision was $7.6 \%$. The analytical accuracy for $\mathrm{Hg}$ in Seronorm trace elements whole blood (Lot. MR4206 and 0512627, SERO AS) was 2.1 $\pm 0.15 \mu \mathrm{g} / \mathrm{l}(\mathrm{N}=115$; recommended: $2-2.4 \mu \mathrm{g} / \mathrm{l})$ and $15.7 \pm 1.3 \mu \mathrm{g} / \mathrm{l}(\mathrm{N}=115$; 
recommended: $16.1-19.7 \mu \mathrm{g} / \mathrm{l})$. The authors express the concentrations as $\mu \mathrm{g} / \mathrm{l}$ :

- $1 \mu \mathrm{g} \mathrm{Cd} / \mathrm{l}=0.0091 \mu \mathrm{mol} / \mathrm{l}$,

- $1 \mu \mathrm{g} \mathrm{Pb} / \mathrm{l}=0.0050 \mu \mathrm{mol} / \mathrm{l}$,

- $1 \mu \mathrm{g} \mathrm{Hg} / \mathrm{l}=0.0050 \mu \mathrm{mol} / \mathrm{l}$.

All analyses of a given urinary parameter were performed under similar experimental conditions within 6 months of collection at the Environmental and Industrial Toxicology Laboratory of the Catholic University of Louvain (UCLBrussels, Belgium). Albumin (Alb-U), and retinol-binding protein (RBP-U) in urine were quantified by latex immunoassay [20] and urinary creatinine (Creat-U) by the Jaffe method [16].

\section{ETHICS}

The approval of the local ethics committee in the Moroccan Health Ministry (Centre Hospitalier Universitaire (CHU) Hassan II; Fez; Morocco) was obtained at the beginning of the study. Contact was established first with the school management and then with parents and children with questionnaires containing a written description of the study. A written consent was obtained from a parent of each child. An oral consent was obtained from each child before sampling.

\section{STATISTICS}

The statistical part of the study focused on the analysis of the variability in the concentrations of heavy metals: cadmium, mercury and lead, and those of kidney markers: urinary creatinine, albumin and RBP according to different parameters; such as the study area (urban, industrial or rural), sex (girls or boys), age, body mass index (BMI), amalgams. The rate variability of heavy metals and renal markers for different parameters of variation were studied by a multivariate analysis of variance performed by the GLM procedure of SAS software taking into consideration unbalanced numbers. Multiple comparisons of means and their classification are provided by the Duncan test whenever the analysis of variance revealed significant differences [21,22].

Moreover, the analysis of the variability of heavy metals and renal markers concentrations is complemented by a correlation analysis (Pearson's test) in order to quantify the relationship that may exist between the examined variables. A statistical analysis was carried out with the SAS statistical package. Geometric means were used for describing average levels, results are expressed as mean \pm standard deviation, and statistical significance was set as $\mathrm{p}<0.05$.

\section{RESULTS}

The mean of blood lead levels (BLLs) in the whole population of children $(\mathrm{N}=196)$ was $55.531 \mu \mathrm{g} / \mathrm{l}$ (range: $7.5-$ $231.141 \mu \mathrm{g} / \mathrm{l})$. In the urban area, the BLLs mean was much higher $(\mathrm{N}=49, \mathrm{M} \pm \mathrm{SD}: 82.365 \pm 45.9 \mu \mathrm{g} / \mathrm{l})$ than in the industrial area $(\mathrm{N}=66, \mathrm{M} \pm \mathrm{SD}: 48.231 \pm 20.8 \mu \mathrm{g} / \mathrm{l})$, which was also higher than the mean in the control area (rural area; $\mathrm{N}=81, \mathrm{M} \pm \mathrm{SD}: 35.991 \pm 22.8 \mu \mathrm{g} / \mathrm{l})$ with $\mathrm{p}<0.0001$ (results not shown in tables). We obtained relatively similar results after data analysis of boys and girls separately as can be seen in Tables 1 and 2. No significant difference between boys and girls was noticed in various areas (Table 3 ). Figure 2 indicates that children with $\mathrm{Pb}-\mathrm{B}$ above the Centre for Disease Control and Prevention's (CDC) level of concern $(100 \mu \mathrm{g} / \mathrm{l})[23]$ represented about $8 \%$ of the population (among whom about $75 \%$ lived in the urban area). Apart from the area of residence, BLLs were associated with passive smoking and infancy in an urban area (Table 4). The mean of blood cadmium levels (BCLs) in all children was $0.221 \mu \mathrm{g} / \mathrm{l}$ (range: 0.067-0.676 $\mu \mathrm{g} / \mathrm{l}$ ). There was no difference between various areas (Table 1 and 2). The only difference between boys and girls was in the rural area, where boys had a higher BCLs 
Table 1. Toxic metals exposure and renal parameters in girls living in the 3 areas of Fez, Morocco

\begin{tabular}{|c|c|c|c|c|c|c|c|c|}
\hline Parameter & Area & $\begin{array}{l}\text { Girls } \\
\text { (n) }\end{array}$ & M & SD & Min. & Max & $\begin{array}{c}\text { 2-way ANOVA } \\
\text { (p) }\end{array}$ & Sign. \\
\hline \multirow[t]{3}{*}{ Age (years) } & rural & 48 & $9.521^{\mathrm{a}}$ & 1.879 & 6.000 & 12.000 & & \\
\hline & industrial & 40 & $8.375^{\mathrm{b}}$ & 1.333 & 6.000 & 12.000 & 0.0058 & $* *$ \\
\hline & urban & 26 & $9.346^{\mathrm{a}}$ & 1.831 & 7.000 & 12.000 & & \\
\hline \multirow[t]{3}{*}{ BMI } & rural & 48 & $15.372^{\mathrm{a}}$ & 1.798 & 11.421 & 20.254 & & \\
\hline & industrial & 40 & $16.201^{\mathrm{a}}$ & 2.653 & 9.722 & 22.857 & 0.197 & ns \\
\hline & urban & 26 & $15.807^{\mathrm{a}}$ & 1.791 & 13.125 & 20.384 & & \\
\hline \multirow[t]{3}{*}{$\mathrm{Pb}-\mathrm{B}(\mu \mathrm{g} / \mathrm{l})$} & rural & 47 & $33.279^{c}$ & 17.027 & 7.500 & 94.265 & & \\
\hline & industrial & 34 & $48.701^{\mathrm{b}}$ & 21.673 & 19.303 & 110.433 & $<0.001$ & $* * *$ \\
\hline & urban & 26 & $89.451^{\mathrm{a}}$ & 54.874 & 35.745 & 231.141 & & \\
\hline \multirow[t]{3}{*}{ Cd-B $(\mu \mathrm{g} / \mathrm{l})$} & rural & 47 & $0.187^{\mathrm{a}}$ & 0.056 & 0.086 & 0.341 & & \\
\hline & industrial & 34 & $0.224^{a}$ & 0.102 & 0.067 & 0.471 & 0.086 & ns \\
\hline & urban & 26 & $0.222^{\mathrm{a}}$ & 0.102 & 0.072 & 0.473 & & \\
\hline \multirow[t]{3}{*}{$\operatorname{Hg}-\mathrm{B}(\mu \mathrm{g} / \mathrm{l})$} & rural & 46 & $0.275^{b}$ & 0.298 & 0.035 & 1.524 & & \\
\hline & industrial & 33 & $0.591^{\mathrm{a}}$ & 0.807 & 0.074 & 4.248 & 0.026 & $*$ \\
\hline & urban & 26 & $0.713^{\mathrm{a}}$ & 1.041 & 0.053 & 5.313 & & \\
\hline \multirow[t]{3}{*}{ Creat-U (g/l) } & rural & 42 & $0.983^{\mathrm{a}}$ & 0.471 & 0.318 & 2.633 & & \\
\hline & industrial & 32 & $1.262^{\mathrm{a}}$ & 0.526 & 0.411 & 2.256 & 0.059 & ns \\
\hline & urban & 21 & $1.025^{\mathrm{a}}$ & 0.449 & 0.415 & 2.102 & & \\
\hline \multirow[t]{3}{*}{ RBP-U (g/g Creat) } & rural & 41 & $131.161^{\mathrm{a}}$ & 62.091 & 19.413 & 304.412 & & \\
\hline & industrial & 32 & $140.557^{\mathrm{a}}$ & 129.994 & 7.206 & 703.456 & 0.879 & ns \\
\hline & urban & 21 & $141.695^{\mathrm{a}}$ & 85.231 & 37.452 & 381.028 & & \\
\hline \multirow[t]{3}{*}{ Alb-U (g/g Creat) } & rural & 42 & $28.194^{\mathrm{a}}$ & 48.045 & 1.319 & 185.536 & & \\
\hline & industrial & 32 & $20.542^{\mathrm{a}}$ & 38.014 & 1.218 & 173.000 & 0.456 & ns \\
\hline & urban & 21 & $36.643^{\mathrm{a}}$ & 66.591 & 3.134 & 279.202 & & \\
\hline
\end{tabular}

BMI - body mass index; Pb-B - blood lead; Cd-B - blood cadmium; Hg-B - total blood mercury; Creat-U - urinary creatinine; RBP-U - urinary RBP (retinol bending protein); Alb-U - urinary albumin.

M - mean; SD - standard deviation; min. - minimal value; max - maximal value; $\mathrm{p}$ - value of Student's t-test (test of comparison between means); Sign. - significance of the difference between means; ns - not significant.

* $\mathrm{p}<0.05 ; * \mathrm{p}<0.01 ; * * \mathrm{p}<0.001$.

${ }^{a}$ Means with the same letter are not significantly different.

a, b,c Means with different letters are significantly different.

Table 2. Toxic metals exposure and renal parameters in boys living in the 3 areas of Fez, Morocco

\begin{tabular}{llccccccc}
\hline \multicolumn{1}{c}{ Parameter } & \multicolumn{1}{c}{ Area } & $\begin{array}{c}\text { Boys } \\
(\mathrm{n})\end{array}$ & $\mathrm{M}$ & $\mathrm{SD}$ & Min. & Max & $\begin{array}{c}\text { 2-way ANOVA } \\
(\mathrm{p})\end{array}$ & Sign. \\
\hline Age (years) & rural & 35 & $9.457^{\mathrm{a}}$ & 1.899 & 7 & 12 & & \\
& industrial & 38 & $8.131^{\mathrm{b}}$ & 1.143 & 6 & 10 & $<0.0001$ & $* * *$ \\
& urban & 24 & $9.958^{\mathrm{a}}$ & 1.601 & 6 & 12 & & \\
\hline
\end{tabular}


Table 2. Toxic metals exposure and renal parameters in boys living in the 3 areas of Fez, Morocco - cont.

\begin{tabular}{|c|c|c|c|c|c|c|c|c|}
\hline Parameter & Area & $\begin{array}{l}\text { Boys } \\
\text { (n) }\end{array}$ & M & SD & Min. & Max & $\begin{array}{l}\text { 2-way ANOVA } \\
\text { (p) }\end{array}$ & Sign. \\
\hline \multirow[t]{3}{*}{ BMI } & rural & 35 & $15.483^{b}$ & 2.208 & 11.056 & 19.396 & & \\
\hline & industrial & 38 & $16.971^{\mathrm{a}}$ & 2.252 & 14.117 & 24.615 & 0.011 & $*$ \\
\hline & urban & 24 & $16.313^{\mathrm{a}}$ & 1.477 & 14.211 & 19.545 & & \\
\hline \multirow[t]{3}{*}{$\mathrm{Pb}-\mathrm{B}(\mu \mathrm{g} / \mathrm{l})$} & rural & 34 & $39.753^{b}$ & 28.843 & 12.983 & 171.933 & & \\
\hline & industrial & 32 & $47.736^{\mathrm{b}}$ & 20.191 & 22.931 & 89.966 & $<0.0001$ & $* * *$ \\
\hline & urban & 23 & $74.357^{\mathrm{a}}$ & 32.682 & 38.161 & 168.441 & & \\
\hline \multirow{3}{*}{ Cd-B ( $\mu \mathrm{g} / \mathrm{l})$} & rural & 34 & $0.232^{\mathrm{a}}$ & 0.116 & 0.101 & 0.676 & & \\
\hline & industrial & 32 & $0.217^{\mathrm{a}}$ & 0.093 & 0.072 & 0.582 & 0.604 & $\mathrm{~ns}$ \\
\hline & urban & 23 & $0.206^{\mathrm{a}}$ & 0.079 & 0.117 & 0.398 & & \\
\hline \multirow[t]{3}{*}{$\mathrm{Hg}-\mathrm{B}(\mu \mathrm{g} / \mathrm{l})$} & rural & 34 & $0.176^{\mathrm{b}}$ & 0.131 & 0.015 & 0.625 & & \\
\hline & industrial & 31 & $0.683^{\mathrm{a}}$ & 0.555 & 0.091 & 2.324 & 0.0007 & $* * *$ \\
\hline & urban & 23 & $0.443^{\mathrm{a}}$ & 0.709 & 0.067 & 3.519 & & \\
\hline \multirow[t]{3}{*}{ Creat-U (g/l) } & rural & 32 & $1.002^{\mathrm{a}}$ & 0.418 & 0.213 & 2.095 & & \\
\hline & industrial & 30 & $1.147^{\mathrm{a}}$ & 0.643 & 0.44 & 3.827 & 0.416 & ns \\
\hline & urban & 22 & $0.969^{\mathrm{a}}$ & 0.419 & 0.286 & 1.828 & & \\
\hline \multirow[t]{3}{*}{ RBP-U (g/g Creat) } & rural & 32 & $145.653^{\mathrm{a}}$ & 89.491 & 22.178 & 475.107 & & \\
\hline & industrial & 29 & $111.181^{\mathrm{a}}$ & 93.591 & 4.678 & 354.229 & 0.231 & ns \\
\hline & urban & 22 & $118.341^{\mathrm{a}}$ & 53.305 & 40.269 & 227.693 & & \\
\hline \multirow[t]{3}{*}{ Alb-U (g/g Creat) } & rural & 31 & $15.754^{\mathrm{a}}$ & 44.642 & 0.02 & 240.828 & & \\
\hline & industrial & 30 & $9.629^{\mathrm{a}}$ & 22.382 & 0.389 & 114.900 & 0.452 & ns \\
\hline & urban & 22 & $4.939^{\mathrm{a}}$ & 3.126 & 1.808 & 14.411 & & \\
\hline
\end{tabular}

Abbreviations as in Table 1.

Table 3. Toxic metals exposure and renal parameters according to sex in children from the 3 areas of Fez, Morocco

\begin{tabular}{|c|c|c|c|c|c|c|c|c|c|c|c|c|}
\hline \multirow[b]{2}{*}{ Parameter } & \multirow[b]{2}{*}{ Area } & \multicolumn{5}{|c|}{ Girls } & \multicolumn{5}{|c|}{ Boys } & \multirow{2}{*}{$\begin{array}{c}\mathrm{p} \\
\text { (2-way } \\
\text { ANOVA) } \\
\text { (Sign.) }\end{array}$} \\
\hline & & $\mathrm{n}$ & M & SD & $\min$ & $\max$ & $\mathrm{n}$ & M & SD & $\min$. & $\max$ & \\
\hline \multirow[t]{3}{*}{ Age (years) } & rural & 48 & 9.521 & 1.879 & 6 & 12 & 35 & 9.457 & 1.899 & 7 & 12 & 0.879 \\
\hline & industrial & 40 & 8.375 & 1.333 & 6 & 12 & 38 & 8.131 & 1.143 & 6 & 10 & 0.391 \\
\hline & urban & 26 & 9.346 & 1.831 & 7 & 12 & 24 & 9.958 & 1.601 & 6 & 12 & 0.216 \\
\hline \multirow[t]{3}{*}{ BMI } & rural & 48 & 15.372 & 1.798 & 11.422 & 20.255 & 35 & 15.483 & 2.208 & 11.056 & 19.396 & 0.801 \\
\hline & industrial & 40 & 8.375 & 1.333 & 9.722 & 22.857 & 38 & 8.131 & 1.143 & 14.118 & 24.615 & 0.391 \\
\hline & urban & 26 & 0.346 & 1.831 & 13.125 & 20.385 & 24 & 9.958 & 1.601 & 14.211 & 19.545 & 0.216 \\
\hline \multirow[t]{3}{*}{$\mathrm{Pb}-\mathrm{B}(\mu \mathrm{g} / \mathrm{l})$} & rural & 47 & 33.278 & 17.026 & 7.500 & 94.265 & 34 & 39.753 & 28.842 & 12.983 & 171.933 & 0.215 \\
\hline & industrial & 34 & 48.701 & 21.673 & 19.303 & 110.433 & 32 & 47.736 & 20.191 & 22.931 & 89.966 & 0.851 \\
\hline & urban & 26 & 89.449 & 54.873 & 35.745 & 231.141 & 23 & 74.356 & 32.682 & 38.161 & 168.441 & 0.261 \\
\hline
\end{tabular}


Table 3. Toxic metals exposure and renal parameters according to sex in children from the 3 areas of Fez, Morocco - cont.

\begin{tabular}{|c|c|c|c|c|c|c|c|c|c|c|c|c|}
\hline \multirow[b]{2}{*}{ Parameter } & \multirow[b]{2}{*}{ Area } & \multicolumn{5}{|c|}{ Girls } & \multicolumn{5}{|c|}{ Boys } & \multirow{2}{*}{$\begin{array}{c}\mathrm{p} \\
\text { (2-way } \\
\text { ANOVA) } \\
\text { (Sign.) }\end{array}$} \\
\hline & & $\mathrm{n}$ & M & SD & $\min$. & $\max$ & $\mathrm{n}$ & M & SD & $\min$. & $\max$ & \\
\hline \multirow[t]{3}{*}{$\mathrm{Cd}-\mathrm{B}(\mu \mathrm{g} / \mathrm{l})$} & rural & 47 & $0.186^{b}$ & 0.055 & 0.086 & 0.341 & 34 & $0.232^{\mathrm{a}}$ & 0.116 & 0.101 & 0.676 & $0.023^{*}$ \\
\hline & industrial & 34 & 0.223 & 0.102 & 0.067 & 0.471 & 32 & 0.216 & 0.093 & 0.072 & 0.582 & 0.783 \\
\hline & urban & 26 & 0.221 & 0.101 & 0.072 & 0.473 & 23 & 0.206 & 0.079 & 0.117 & 0.398 & 0.542 \\
\hline \multirow[t]{3}{*}{$\mathrm{Hg}-\mathrm{B}(\mu \mathrm{g} / \mathrm{l})$} & rural & 46 & 0.275 & 0.297 & 0.035 & 1.524 & 34 & 0.175 & 0.131 & 0.015 & 0.625 & 0.076 \\
\hline & industrial & 33 & 0.591 & 0.807 & 0.074 & 4.248 & 31 & 0.683 & 0.554 & 0.091 & 2.324 & 0.586 \\
\hline & urban & 26 & 0.713 & 1.041 & 0.053 & 5.313 & 23 & 0.443 & 0.709 & 0.067 & 3.519 & 0.141 \\
\hline \multirow[t]{3}{*}{ Creat-U (g/l) } & rural & 42 & 0.983 & 0.471 & 0.318 & 2.633 & 32 & 1.001 & 0.418 & 0.213 & 2.095 & 0.859 \\
\hline & industrial & 32 & 1.262 & 0.526 & 0.411 & 2.256 & 30 & 1.147 & 0.643 & 0.439 & 3.827 & 0.497 \\
\hline & urban & 21 & 1.025 & 0.449 & 0.415 & 2.102 & 22 & 0.969 & 0.418 & 0.286 & 1.828 & 0.664 \\
\hline \multirow[t]{3}{*}{ RBP-U (g/g Creat) } & rural & 41 & 131.161 & 62.091 & 19.413 & 304.412 & 32 & 145.652 & 89.491 & 22.178 & 475.107 & 0.444 \\
\hline & industrial & 32 & 140.557 & 129.994 & 7.206 & 703.456 & 29 & 111.181 & 93.591 & 4.678 & 354.229 & 0.261 \\
\hline & urban & 20 & 141.695 & 85.231 & 37.452 & 381.028 & 22 & 118.341 & 53.305 & 40.269 & 227.693 & 0.317 \\
\hline \multirow[t]{3}{*}{ Alb-U (g/g Creat) } & rural & 42 & 28.193 & 48.045 & 1.319 & 185.536 & 31 & 15.754 & 44.641 & 0.020 & 240.828 & 0.279 \\
\hline & industrial & 32 & 20.542 & 38.013 & 1.218 & 173.000 & 30 & 9.629 & 22.382 & 0.389 & 114.901 & 0.136 \\
\hline & urban & 21 & $36.643^{\mathrm{a}}$ & 66.591 & 3.134 & 279.202 & 22 & $4.939^{\mathrm{b}}$ & 3.126 & 1.808 & 14.411 & $0.037^{*}$ \\
\hline
\end{tabular}

Means without any letter are not significantly different, means with different letters $\left({ }^{\mathrm{a}},{ }^{\mathrm{b}}\right)$ are significantly different at $\mathrm{p}<0.05\left(^{*}\right)$.

Other abbreviations as in Table 1.

mean than girls (Table 3). As shown in Table 4, BCLs were associated with the number of cigarettes smoked at children's homes. The mean of the blood mercury levels

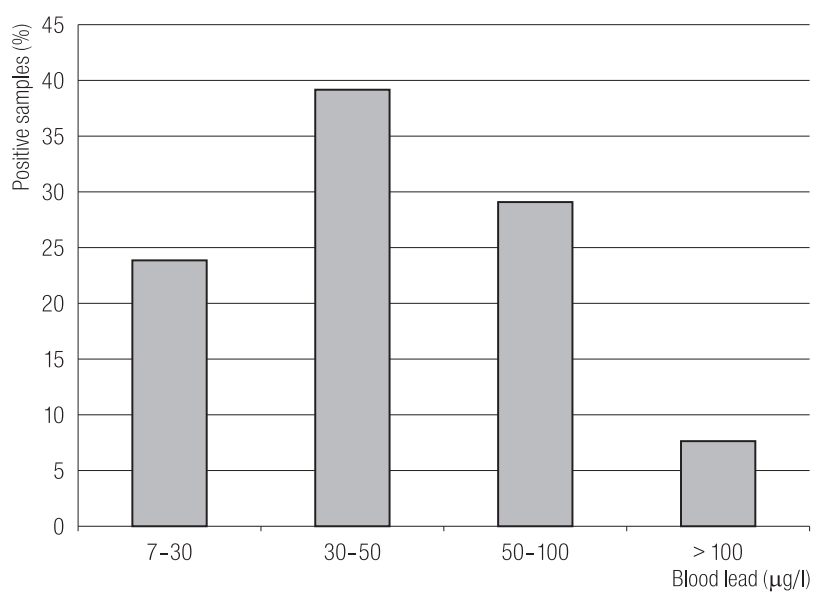

Fig. 2. Frequency of lead detection in blood samples from the studied population of children $(\mathrm{N}=196)$
(BMLs) in our population was $0.491 \mu \mathrm{g} / \mathrm{l}$ (range: $0.015-$ $5.313 \mu \mathrm{g} / \mathrm{l})$. The BMLs mean was higher in urban and industrial areas than in the control area (Tables 1 and 2) with no gender-related difference (Table 3). The BMLs were associated with amalgam fillings and infancy in the urban area (Table 4).

Pearson's test indicated in the whole population ( $\mathrm{N}=196)$ a negative correlation between BLLs and the urinary creatinine concentrations $(\mathrm{r}=-0.174, \mathrm{p}=0.025)$, but no correlations were found between BLLs and urinary markers Alb-U and RBP-U ( $p=0.589$ and $p=0.064$, respectively). Nevertheless, BLLs were negatively correlated with height in girls from the urban area $(\mathrm{N}=25, \mathrm{r}=-0.425$, $\mathrm{p}=0.034$ ), and as can be seen in Table 3 , the urinary albumin mean in these girls was high enough $(36.643 \mu \mathrm{g} / \mathrm{l})$ to be considered as microalbuminuria. These subtle effects 
Table 4. The effect of various factors on toxic metals concentrations in blood among children of Fez, Morocco

\begin{tabular}{|c|c|c|c|c|c|c|c|c|c|c|}
\hline Factor & Group & $\begin{array}{l}\text { Children } \\
\text { (n) }\end{array}$ & $\begin{array}{c}\mathrm{Pb}-\mathrm{B}(\mathrm{M} \pm \mathrm{SD}) \\
(\mu \mathrm{g} / \mathrm{l})\end{array}$ & $\mathrm{p}$ & $\begin{array}{l}\text { Children } \\
\text { (n) }\end{array}$ & $\begin{array}{c}\text { Cd-B }(M \pm S D) \\
(\mu \mathrm{g} / \mathrm{l})\end{array}$ & $\mathrm{p}$ & $\begin{array}{l}\text { Children } \\
\text { (n) }\end{array}$ & $\begin{array}{c}\mathrm{Hg}-\mathrm{B}(\mathrm{M} \pm \mathrm{SD}) \\
(\mu \mathrm{g} / \mathrm{l})\end{array}$ & $\mathrm{p}$ \\
\hline \multirow[t]{2}{*}{ Amalgams use } & I & 5 & $83.176^{\mathrm{a}} \pm 55.494$ & $0.148^{\text {ns }}$ & 5 & $0.251^{\mathrm{a}} \pm 0.103$ & $0.978^{\mathrm{ns}}$ & 5 & $1.499^{\mathrm{a}} \pm 1.385$ & $0.0004^{* * *}$ \\
\hline & II & 191 & $50.885^{\mathrm{a}} \pm 34.087$ & & 191 & $0.212^{\mathrm{a}} \pm 0.092$ & & 188 & $0.429^{b} \pm 0.601$ & \\
\hline \multirow{2}{*}{$\begin{array}{l}\text { Exposure } \\
\text { to passive } \\
\text { smoking at } \\
\text { home }\end{array}$} & I & 51 & $58.164^{\mathrm{a}} \pm 45.519$ & $0.04 *$ & 51 & $0.203^{\mathrm{a}} \pm 0.081$ & $0.343^{\text {ns }}$ & 51 & $0.498^{\mathrm{a}} \pm 0.615$ & $0.44^{\mathrm{ns}}$ \\
\hline & II & 145 & $49.439^{b} \pm 30.242$ & & 145 & $0.216^{\mathrm{a}} \pm 0.095$ & & 142 & $0.441^{\mathrm{a}} \pm 0.662$ & \\
\hline \multirow{3}{*}{$\begin{array}{l}\text { Number of } \\
\text { cigarettes } \\
\text { smoked } \\
\text { inside the } \\
\text { child's home } \\
\text { per day }\end{array}$} & I & 86 & $48.916^{\mathrm{a}} \pm 29.096$ & & 86 & $0.219^{b} \pm 0.093$ & & 85 & $0.511^{\mathrm{a}} \pm 0.808$ & \\
\hline & II & 83 & $52.945^{\mathrm{a}} \pm 42.402$ & $0.523^{\mathrm{ns}}$ & 83 & $0.196^{\mathrm{b}} \pm 0.071$ & $0.018^{*}$ & 81 & $0.431^{\mathrm{a}} \pm 0.545$ & $0.392^{\mathrm{ns}}$ \\
\hline & III & 27 & $56.803^{\mathrm{a}} \pm 25.356$ & & 27 & $0.246^{\mathrm{a}} \pm 0.128$ & & 27 & $0.362^{\mathrm{a}} \pm 0.245$ & \\
\hline \multirow{2}{*}{$\begin{array}{l}\text { Infancy in urban } \\
\text { environment }\end{array}$} & I & 124 & $60.685^{\mathrm{a}} \pm 37.472$ & $0.006^{* *}$ & 124 & $0.217^{\mathrm{a}} \pm 0.093$ & $0.891^{\text {ns }}$ & 122 & $0.605^{\mathrm{a}} \pm 0.769$ & $0.002 * *$ \\
\hline & II & 72 & $36.251^{b} \pm 23.214$ & & 72 & $0.205^{\mathrm{a}} \pm 0.091$ & & 71 & $0.201^{b} \pm 0.165$ & \\
\hline
\end{tabular}

For the factor "Number of cigarettes smoked inside the child's home per day" - group I: "0", group II: "1-4", group III: " $\geq 5$ cigarettes".

For other factors: group I: "yes"; group II: "no".

Other abbreviations as in Table 1.

in girls from the inner city of Fez can be related to the high BLLs in these girls that had the highest BLLs mean in our population $(89.451 \mu \mathrm{g} / \mathrm{l})$ (Table 1$)$.

\section{DISCUSSION}

\section{Blood lead}

In Morocco, there was just one study describing lead in hair of 327 school children living in a wastewater spreading field of Marrakesh city in the south of Morocco (1999) and it reported the mean of $14.8 \pm 4.5 \mu \mathrm{g} / \mathrm{g}$ in exposed children that was not significantly different from the mean obtained in the control area [24]. Few studies concern blood toxic metals environmental exposure in children in the neighboring countries. In Egypt, a study undertaken during the phase of leaded petrol in 126 traffic policemen in Cairo city reported a high mean of BLLs $(292 \pm 75 \mu \mathrm{g} / \mathrm{l})$ and a high hemoglobin concentration in the examined subjects in comparison with the control group. This occupational exposure indicated a potential risk from traffic-exhaust-induced air pollution for other groups of the Cairo population, such as children and pregnant women [25].

The mean of blood lead levels $(\mathrm{Pb}-\mathrm{B})$ in all children of our population was $55.531 \mu \mathrm{g} / \mathrm{l}$ (girls: $57.142 \mu \mathrm{g} / \mathrm{l}$, boys: $53.954 \mu \mathrm{g} / \mathrm{l})$. This BLLs mean is in accordance with the one found in 190 Egyptian school children of the same age range $(62.2 \mu \mathrm{g} / \mathrm{l})$ exposed to high traffic density around their school [26], but it is lower in comparison with the mean reported by Mostafa GA in 2009 for 100 children from Cairo city (median: $90 \mu \mathrm{g} / \mathrm{l}$, range: $30-280 \mu \mathrm{g} / \mathrm{l}$ ). Such a high BLLs median, that can be related to high exposure of children to traffic exhausts in the mega city of Cairo, is however comparable to the BLLs mean that we found in the urban area $(82.36 \mu \mathrm{g} / \mathrm{l})$ [27].

The comparison of the BLLs mean of all children in this study with the means reported in other countries indicates that BLLs mean in our series is higher than the means reported recently in most Central Europe cities and in $\mathrm{Ca}$ nadian children with the same age range, with $\mathrm{Pb}$ - $\mathrm{B}$ means 
ranging between $10 \mu \mathrm{g} / \mathrm{l}$ and $20 \mu \mathrm{g} / \mathrm{l}$ [28-30]. Children with a BLLs mean above the Centre for Disease Control and Prevention's (CDC) level of concern ( $\geq 100 \mu \mathrm{g} / \mathrm{l})$ [23] represented about $8 \%$ of the population (out of whom $75 \%$ lived in the urban area), this percentage is lower that the percentage reported in the studies on Egyptian children (25\% and $43 \%$, respectively) [26,27]. About $30 \%$ of children had BLLs between $50 \mu \mathrm{g} / \mathrm{l}$ and $100 \mu \mathrm{g} / \mathrm{l}$ (out of whom about $50 \%$ lived in the urban area) (see Figure 2). The absence of the gender-related influence on BLLs fits in with other studies in children [31].

The mean of BLLs in the urban area $(82.361 \mu \mathrm{g} / \mathrm{l})$ is much higher than the means reported in French children (8-12 years old) exposed to non-ferrous smelters pollution and in children (8-11 years old) inhabiting French industrial areas (39.5 and 34.8, respectively) [32,33]. It is also much higher than the BLLs means in urban areas in Canada (children aged 6-11 years, $10.2 \mu \mathrm{g} / \mathrm{l}$ ) and in Brazil (children aged 6-8 years, $24 \mu \mathrm{g} / \mathrm{l})[30,34]$. The BLLs in our series are however comparable to other studies in children exposed to roads with heavy traffic, e.g., studies conducted in India (children aged 3-12 years) and in Uruguay (children aged 2-14 years) cities reported BLLs of $93.2 \mu \mathrm{g} / \mathrm{l}$ and $94 \mu \mathrm{g} / \mathrm{l}$, respectively [35,36]. Interestingly, these studies reported the proximity to traffic as the main determinant of high BLLs in children.

Our findings concerning BLLs means in the 3 areas (Tables 1 and 2) indicate a great effect of exposure to traffic exhausts of highways on BLLs in girls and boys from the urban area (a significantly higher BLLs mean than the means in the industrial and control areas); in comparison with the effect of industrial emissions, that is absent in boys for whom no significant difference in the BLLs mean was found between the industrial and rural area (Table 2). Girls from the industrial area had a significantly higher BLLs mean than those living in the control area, but this can be attributed to the fact that the mean age of these girls was lower in the industrial area than in the control area (Table 1), and so the girls from the industrial area could be more sensitive to the environmental lead exposure. Then, the effect of industrial emissions in our children, albeit present, remains small. Another observation is the relatively high BLLs mean in children from the rural area that suggests the implication of other determinants of exposure to lead.

The use of leaded gasoline is a major cause of air pollution in urban areas [37]. In Morocco, surprisingly, the use of lead is limited, but it was still used in gasoline in the period when our study was performed (June 2007 - January 2008) [5]. Thus, the traffic exhausts in the urban area located in the inner city of Fez can partly explicate the high BLLs found in children from the urban area, while the relatively high BLLs in children from industrial area can partly be explained by exposure to lead from industrial emissions. The effect of these emissions on BLLs is weaker since they have generally been restricted during the last decade. The BLLs mean is low in the control area (rural area) that is located far from the traffic exhausts and the industrial emissions. Matheea et al. reported in a study undertaken in 2002 in 429 children (5-11 years old) that the introduction of unleaded petrol in South Africa (in 1996) produced significant reductions in the mean $\mathrm{Pb}-\mathrm{B}$ concentrations among Cape Peninsula inner city children (from 160 to $64 \mu \mathrm{g} / \mathrm{l}$ ) and in the proportion of children with elevated blood lead levels $\geq 100 \mu \mathrm{g} / \mathrm{l}$ (from $90 \%$ to 10\%) just in six years after the start of Phasing Out Leaded Gasoline [38].

With respect to other lead exposure determinants (Table 4), children exposed to passive smoking had significantly elevated BLLs in comparison to children not exposed to tobacco smoke. The BLLs increased also with the number of cigarettes smoked at the child's home, but not in a significant way $(p=0.52)$. This can be explained by the low number of cigarettes smoked at the children's homes. The exposure to passive smoking can explain well the relatively high BLLs in children from the rural area that are exposed 
neither to heavy traffic nor to industrial emissions. A cigarette generally contains $0.6-17 \mu \mathrm{g}$ of lead $[39,40]$. Many studies showed that parents' smoking habits or passive smoking had an impact on children's BLLs $[9,41]$. Willers et al. even found a dose-response relationship between the amount of tobacco smoked by the mother and BLLs of children [42].

Another determinant of elevated BLLs in children was the infancy in an urban area, therefore, children that had spent their whole childhood in an urban area had higher BLLs ( $p=0.006)$ than those who had just emigrated from the rural area to Fez city. This can mainly be explained by the exposure to traffic exhausts in the urban area and it can confirm our findings in this area.

The adverse health effects associated with elevated BLLs have been widely studied and documented. Children are particularly vulnerable to lead poisoning, even more than adults because they absorb more lead from their environments $[43,44]$. The CDC considers lead poisoning as one of the most common preventable pediatric health problems involving mainly neurological effects in children with BLLs > $100 \mu \mathrm{g} / \mathrm{l}(0.5 \mu \mathrm{mol} / \mathrm{dl})$ [23]. Therefore, about $8 \%$ of the children in our sample that have BLLs $>100 \mu \mathrm{g} / \mathrm{l}$ need a strict medical followup. Many reports have documented evident adverse effects of BLLs $<100 \mu \mathrm{g} / \mathrm{l}$ in children. Thus, children that have BLLs 50-100 $\mu \mathrm{g} / \mathrm{l}$ (approximately $30 \%$ of children in our population particularly those living in the urban area; see Figure 2) are likely to suffer from neurocognitive and behavioral deleterious effects. It has been revealed that attention, executive functions, visualmotor reasoning skills (IQ scores), vestibular-propioceptive control, and social behavior are especially affected $[45,46]$.

For these reasons, the declaration of Brescia on metal neurotoxicity recommended that the $\mathrm{B}-\mathrm{Pb}$ action level for children should be reduced to $50 \mu \mathrm{g} / \mathrm{l}$ in nations worldwide [47]. Furthermore, other findings suggest that there may be no threshold for the adverse consequences of lead exposure [48,49].

In addition, Menke et al. (2006) found that BLL was significantly associated with both myocardial infarction and stroke mortality at BLLs $>20 \mu \mathrm{g} / \mathrm{l}$, approximately 5-times lower than the recommended limit of CDC [50]. In this case, even the children having BLLs 30-50 $\mu \mathrm{g} / 1$, that represent about $40 \%$ of our population (Figure 2), especially those living in the urban area, are likely to suffer from adverse effects of lead exposure, particularly if the environmental exposure remains at this level.

As regards renal effects of lead exposure, as shown in Tables 1 and 2, none of the renal parameters studied showed any statistically significant difference between children in the 3 areas, either in girls or in boys. The influence of lead exposure on the renal parameters studied was further assessed by Pearson coefficient in all children $(N=164)$ that revealed a negative correlation between BLLs and the urinary creatinine concentrations $(\mathrm{r}=-0.174, \mathrm{p}=0.025)$. The urinary creatinine is not commonly used as the serum creatinine in evaluating lead renal effects, but this negative correlation at such a low level of exposure can indicate negative effects of environmental lead on the glomerular filtration rate in children, (evaluated generally with the creatinine clearance [51]), particularly those with high BLLs.

No correlations were found between BLLs either with urinary albumin (Alb-U) or with urinary RBP (RBP-U) ( $p=0.589$ and $p=0.064$, respectively). However, a strong positive correlation was found between Alb-U and RBP-U $(\mathrm{r}=0.361, \mathrm{p}<0.0001)$ indicating that glomerular and tubular alterations can occur simultaneously and may considerably affect the renal function in these children (particularly girls with high Alb-U levels).

In addition, positive correlations were found between BLLs and BCLs ( $r=0.207, p=0.0035)$, between BLLs and BMLs ( $r=0.348, p<0.0001)$, and between BCLs and BMLs $(r=0.681, p<0.0001)$. Mercury 
was observed to increase the toxic effects of lead on the glomerular filtration function and to potentiate cadmium effects on the renal tubular function. On the other hand, lead and cadmium had some competitive effects [52]. These strong positive correlations found between the trace elements studied in our population indicate eventual interactions between them. This can probably increase lead toxic effects in children even at a low environmental level of exposure.

No correlations between trace elements and renal markers were found after data analysis of every area separately. In order to further analyze possible renal effects of lead exposure in children, we checked for any correlations between renal markers and BLLs within the smaller subgroups of children with high BLLs (above $50 \mu \mathrm{g} / 1,70 \mu \mathrm{g} / 1$ and $100 \mu \mathrm{g} / 1$ ), but no correlation was detected in these subgroups.

This finding was in accordance with other studies describing renal biomarker anomalies in children at a low level of environmental exposure to lead [32,15]. Nevertheless, when we further analyzed the outcomes concerning BLLs effects on physical development of children, the only results found significant concerned girls from the urban area $(\mathrm{N}=25)$ that had the highest BLLs mean in our population $(89.451 \mu \mathrm{g} / \mathrm{l})($ Table 1$)$, and for whom BLLs were negatively correlated with height $(r=-0.425, p=0.034)$ and even negatively correlated with weight, but without clear significance $(r=-0.369, \mathrm{p}=0.069)$.

Yang et al. (2012) [53] reported the same finding in Chinese children (3-8 years of age; BLLs mean: $73 \mu \mathrm{g} / \mathrm{l}$ ) exposed to electronic waste. It has been known that lead affects negatively the physical development of children by blocking the absorption of calcium, iron and other elements, and inhibiting the synthesis and utilization of some hormones [54,55]. Many studies also showed that high BLLs had a negative correlation with children's stature [56,57]. Another remarkable finding in girls from the inner city area was the high mean of urinary albumin $(36.643 \mathrm{mg} / \mathrm{g}$ creatinine) (Table 3). The American Diabetes Association (2004) [58] considers Alb-U $\geq 30 \mathrm{mg} / \mathrm{g}$ creatinine (microalbuminuria) as the earliest clinical evidence of chronic nephropathy in children.

These effects in girls from the inner city of Fez can be related to the high BLLs in these girls that had the highest BLLs mean in our population $(89.451 \mu \mathrm{g} / \mathrm{l})$ and among whom we noticed the highest $\mathrm{Pb}-\mathrm{B}$ value in our series $(231.141 \mu \mathrm{g} / \mathrm{l})$. Therefore, even a low environmental level of lead exposure in children can cause subtle effects in children without clear evidence of a threshold. These findings obtained for the first time in Morocco reinforce the need to control and regulate potential sources of contamination by this trace element. The situation in Fez city indicates the real need to undertake preventive actions for the protection of children from passive smoking; even at home, and governmental actions involving firstly the elimination of any leaded petrol in Morocco (officially used or in the black market).

\section{Blood cadmium}

The mean of blood cadmium levels (BCLs) in all children was $0.221 \mu \mathrm{g} / \mathrm{l}$ (girls: $0.212 \mu \mathrm{g} / \mathrm{l}$, boys: $0.221 \mu \mathrm{g} / \mathrm{l}$ ). The BCLs means were lower than those reported in 103 primary school children (6-12 years old) in Cairo city $(1.34 \mu \mathrm{g} / \mathrm{l})$ [59] and proved to be lower also in comparison with the means in French, Canadian an Chinese children living in urban areas $(0.48 \mu \mathrm{g} / \mathrm{l}, 0.35 \mu \mathrm{g} / \mathrm{l}$ and $0.69 \mu \mathrm{g} / \mathrm{l}$, respectively) $[32,53,60]$, but they are somehow elevated in comparison with the BCLs means in children from many urban areas in Central Europe cities [28,61-64].

As shown in Table 1 and 2, boys and girls from the 3 areas have very close BCLs means with no significant differences between various areas. This finding demonstrates the limited impact of industrial emissions on BCLs in Fez city. This is in accordance with previous literature demonstrating that the residential area was found not to be a variable, which can affect BCLs [65-67]. 
The only effect of gender was noticed in the rural area, where boys had a higher BCLs mean than girls (Table 3). This finding is in agreement with some previous studies reporting that boys tend to have a higher uptake of environmental heavy metals than girls, principally due to behavioral differences [68].

Another factor that can explain this difference related to gender is shown in Table 4; as the BCLs in children increase with the increasing number of cigarettes smoked at home. This effect of passive smoking was also reported in Cairene (Egypt) children (aged from 6 to 12) environmentally exposed to cadmium [59]. In Morocco, boys in the same range of age studied in our study are more accustomed to be with their fathers-smokers or other mensmokers smoking at home (smoking mothers are not common in Morocco) than girls, and thus they are more exposed to passive smoking. This gender-induced effect was found just in the rural area probably due to the low education level. Men-smokers in the rural areas smoke usually in the presence of boys, while girls are less exposed to this passive smoking (due to social traditions).

Table 4 indicates also that there was no significant difference $(p=0.343)$ between BCLs means in children exposed and non-exposed to parental smoking. This result can be explained by the low number of cigarettes smoked at children's homes. A cigarette contains generally 1-2 $\mu$ g of cadmium $[39,40]$. Shaham et al. reported in 1996 that exposure to cigarette smoke via passive or active smoking was able to increase the BCL by an average of $0.01 \mu \mathrm{g} / 100 \mathrm{ml}$ and this impact is greater whenever the amount of tobacco smoke increases (increasing number of cigarettes smoked per day) [69].

Long-term exposure to $\mathrm{Cd}$ is able to cause considerable kidney and bone damage - particularly tubular proteinuria - and low bone mineral density [70]. Although the threshold value of BCLs beyond $5 \mu \mathrm{g} / \mathrm{l}$ was reported as a risk of intoxication [65,71], recent studies have suggested that estimates of levels of cadmium in the body that produce renal damage in the kidney were too high and that the tolerated cadmium limit defined should be lower [72,73]. In this study, none of the renal parameters studied showed any statistically significant differences between the 3 areas, either in girls or in boys (Tables 1 and 2) and no correlation was found between BCLs and the studied renal markers concentrations.

This finding is in agreement with the results reported by de Burbure et al., conducted in French and Czech 8-12-yearolds with low BCLs (0.48 and $0.23 \mu \mathrm{g} /$, respectively) [32,52], and it is also in agreement with the findings in Egyptian children with a relatively high cadmium level $(1.34 \mu \mathrm{g} / \mathrm{l})$ with no effects of this level on $\alpha$-1-microglobulinuria, suggesting a subclinical renal effect after several years of cumulative exposure in children [59]. Moreover, Cikrt et al. did not find any relationships between Cd-B and Alb-U or RBP-U in adults even with BCLs above $1 \mu \mathrm{g} / 1$ [74].

\section{Total blood mercury}

Very few studies concern blood mercury environmental exposure in children in the neighboring countries. In Egypt, El-baz et al. reported a highly significant increase in the mean hair mercury level in autistic children compared to the control group $(0.79 \pm 0.51$ vs. $0.12 \pm 0.086 \mathrm{ppm}$, respectively) ( $p<0.001$ ), with a mild increase in the mercury level in children with maternal history of dental amalgam fillings and high fish consumption during pregnancy [75]. These interesting findings suggest that biological damage from mercury as a neurotoxic substance, besides genetic susceptibility in the form of reduced ability to excrete mercury and/or increased environmental exposure at key times in development, may play a causal role in autism. The blood mercury levels (BMLs) mean in the whole population of children was $0.491 \mu \mathrm{g} / \mathrm{l}$ (girls: $0.535 \mu \mathrm{g} / \mathrm{l}$, boys: $0.431 \mu \mathrm{g} / \mathrm{l}$ ). This mean is in parity with previous studies in children from urban areas in Croatia $(0.44 \mu \mathrm{g} / \mathrm{l})$, Slovakia $(0.52 \mu \mathrm{g} / \mathrm{l})$, Sweden $(0.43 \mu \mathrm{g} / \mathrm{l})$ [28] and the Czech Republic $(0.42 \mu \mathrm{g} / \mathrm{l}$ and $0.46 \mu \mathrm{g} / \mathrm{l})$ [61,62], but it is higher 
than BMLs means in children from Poland $(0.12 \mu \mathrm{g} / \mathrm{l})[28]$ and from the US $(0.33 \mu \mathrm{g} / \mathrm{l})[76]$. Moreover, no sex-related differences were observed in different areas (Table 3), this absence of the gender influence on BMLs fits in with other studies in children [52,61,62].

As shown in Tables 1 and 2, children from urban and industrial areas had higher BMLs means than the mean recorded for children from the rural area, both in girls and in boys. Environmental exposure to mercury $(\mathrm{Hg})$ comes mainly from fish intake and dental amalgam fillings [4]. Nevertheless, fish intake of children is low and cannot explain this difference. About $79.2 \%$ of children in the industrial area consume just one fish meal every two weeks, and the percentages noticed in children from the urban and rural areas are close $(41.41 \%$ and $40.79 \%$, respectively) (results not shown in tables).

The use of amalgam fillings can however better explain this difference, as $10 \%$ and $14 \%$ of children in the urban and industrial areas, respectively, have amalgams, but no amalgams use was noticed in rural children $(0 \%$; results not shown in tables). Moreover, as can be seen in Table 3, in spite of the infrequent use of dental amalgam fillings in our population and the low BMLs means found, the well known [4] determinant of elemental $\mathrm{Hg}$ was present as children with amalgams had a significantly $(p=0.0004)$ higher BMLs mean than children without amalgam fillings.

The infancy in the urban environment was another determinant of exposure to $\mathrm{Hg}-\mathrm{B}$, thus children that spent their whole childhood in the urban area had a significantly $(p=0.002)$ higher BMLs mean than children who had migrated from a rural area to the Fez city. This finding can be partly explained by the abundance of fish and the easy access to it and to dental care (including amalgam fillings) in the urban and industrial areas compared to the rural area (due to economic factors).

None of the renal markers studied showed any statistically significant difference between the 3 areas, either in girls or in boys (Tables 1 and 2) and no correlation was found between BMLs and the renal parameters indicating a limited impact of $\mathrm{Hg}-\mathrm{B}$ exposure on renal function in children in the light of renal markers used. However, all the present BMLs are much lower than those suspected to cause health effects (> $20 \mu \mathrm{g} / 1)$ [77] since the highest value of $\mathrm{Hg}$-B in our series is $5.313 \mu \mathrm{g} / \mathrm{l}$ and most children had Hg-B below $1 \mu \mathrm{g} / \mathrm{l}$.

\section{CONCLUSION}

There are few environmental studies concerning the impact of low environmental exposure to lead, cadmium and mercury, especially in children who are considered to be more sensitive to adverse effects of trace elements than adults. In Fez city (north of Morocco), this is the first study with a strict control of analytical quality concerning blood concentrations of $\mathrm{Pb}, \mathrm{Cd}$ and $\mathrm{Hg}$ in children, at low environmental level of exposure, and evaluation of some determinants and some early renal effects of this exposure.

This study showed high BLLs in children - especially those from the inner city. BLLs were associated with traffic exhausts (in particular with the still present use of leaded petrol), passive smoking and infancy in an urban area. Renal and developmental effects of lead exposure noticed in children (particularly in girls from the inner city) are suspected to cause several health problems later in life. About $8 \%$ of children in our population need a strict medical follow-up (BLLs $\geq 100 \mu \mathrm{g} / \mathrm{l}$ ) and some nutritional interventions can be undertaken to reduce lead absorption and to provide an adequate amount of calcium in children's diets, as calcium has been found to decrease the intestinal absorption of lead [78].

Further studies with large cohorts and other renal markers in different areas of Morocco have to be conducted to reduce the lack of data concerning the impact of low environmental level of exposure to $\mathrm{Pb}, \mathrm{Cd}$ and $\mathrm{Hg}$ in 
children. BCLs were associated with the number of cigarettes smoked at children's homes. Although these BCLs were relatively low, the situation is far from comforting in Fez city, because $\mathrm{Cd}$ accumulates in the body over time, therefore, even the low levels observed in children now may result in high concentrations in kidneys in the elderly (especially in girls), in particular if exposure remains constant at this level.

In spite of the low levels, BMLs displayed associations with amalgam fillings and infancy in the urban area. BMLs are much lower than those suspected to cause health effects due to low intake of fish and infrequent use of amalgam fillings in children in our population.

These findings obtained for the first time in Morocco reinforce the need to control and regulate potential sources of contamination by these trace elements. This disturbing situation highlights the real need to undertake preventive actions for the protection of children from passive smoking, even at home, and governmental actions involving firstly the elimination of any leaded petrol in Morocco (used officially or in the black market).

\section{REFERENCES}

1. Goyers RA. Toxic effects of metals. In: Klaassen CD, Amdur MO, Doull J, editors. Casarett and Doull's toxicology: The basic science of poisons. 5th ed. New York: McGrawHills; 1996. p. 691-736.

2. Mortada WI, Sobh MA, El-Defrawy MM, Farahat SE. Reference intervals of cadmium, lead and mercury in blood, urine, hair and nails among residents in Mansoura city, Nile Delta, Egypt. Environ Res Sect A. 2002;90:104-10, http:/dx.doi. org/10.1006/enrs.2002.4396.

3. Tripathi RM, Raghunat R, Kumar AV, Sastry VN, Sadasivan S. Atmospheric and children's blood lead as indicators of vehicular traffic and other emission sources in Mumbay, India. Sci Total Environ. 2001;267:101-8, http://dx.doi. org/10.1016/S0048-9697(00)00770-1.
4. Berlin M, Zalups RK, Fowler BA. Mercury. In: Nordberg GF, Fowler BA, Nordberg M, Friberg LT, editors. Handbook on the toxicology of metals. 3rd ed. Amsterdam: Elsevier, Academic Press; 2007. p. 675-727, http://dx.doi. org/10.1016/B978-012369413-3/50088-4.

5. Mem.gov.ma [Internet]. Governmental actions in the Moroccan Ministry of Energy, Mines, Water and Environment in 2008. Section of Documentation [updated 2009 March 1; cited 2009 August 1]. Available from: http://www. mem.gov.ma.

6. Fejjal A. [Industry and industrialization in Fez city]. Mediteranian. 1986;59(4):63-74. French.

7. Pihan JC, Gukert A, Morel JL, editors. Use of wastewater for irrigation and contamination of agricultural production by heavy metals. Proceedings of the 1st Fronco-Moroccan Inter-University Conference; 1987 March 5-8; Fez city, Morocco. Paris: Springer; 1990.

8. Bouhouch S, Lekouch N, Sedki A, Pineau A. Assessment of trace elements levels in drinking water in the city of Marrakech. 1st International Collogue on Water and Environmental Management of Water Resources, Recycling Wastewater and Environment; 1999 June 25-26. Agadir city, Morocco. Paris: Springer; 2002.

9. Baghurst P, Tong SL, McMichael AS, Robertson EF, Wigg NR, Vimpani GV. Determinants of blood lead concentrations to age 5 years in a birth cohort study of children living in the lead smelting city of Port Pirie and surrounding areas. Arch Environ Health. 1992;47:203-10, http://dx.doi. org/10.1080/00039896.1992.9938350.

10. Skerfving S, Bergdahl IA. Lead. In: Nordberg GF, Fowler BA, Nordberg M, Friberg LT, editors. Handbook on the toxicology of metals. 3rd ed. Amsterdam: Elsevier, Academic Press; 2007. p. 599-643.

11. Toxicological profile for cadmium. US Department of Health and Human Services, Public Health Service, Agency for Toxic Substances and Disease Registry, Atlanta, GA [updated 2010 March 2; cited $2010 \mathrm{Jul}$ 2]. Available from: http://www.atsdr. cdc.gov/toxprofiles/tp13.html. 
12. Fels LM, Wunsch M, Baranowski J, Norska-Borowka I, Priée RG, Taylor SA, et al. Adverse effects of chronic low level lead exposure on kidney fonction - A risk group study in children. Nephrol Dial Transplant. 1998;13:2248-56, http://dx.doi.org/10.1093/ndt/13.9.2248.

13. Bernard A, Thielemans N, Roels H, Lauwerys R. Association between NAG-B and cadmium in urine with no evidence of a threshold. Occup Environ Med. 1995b;52:177-180, http:// dx.doi.org/10.1136/oem.52.3.177.

14. Bernard AM, Vyskocil A, Roels H, Kriz J, Kodl M, Lauwerys R. Renal effects in children living in the vicinity of a lead smelter. Environ Res. 1995;68:91-5, http://dx.doi. org/10.1006/enrs.1995.1012.

15. Verberk MM, Willems TE, Verplanke AJ, de Wolff FA. Environmental lead and renal effects in children. Arch Environ Health. 1996;51:83-7, http://dx.doi.org/10.1080/00039896.19 96.9935998.

16. Price RG, Taylor SA, Chivers I, Arce-Tomas M, Crutcher E, Franchini I, et al. Development and validation of new screening tests for nephrotoxic effects. Hum Exp Toxicol. 1996; 15 Suppl 1:S10-19.

17. Bernard A, Hermans C. Biomonitoring of early effects on the kidney or the lung. Sci Total Environ. 1997;199:205-11, http://dx.doi.org/10.1016/S0048-9697(97)05497-1.

18. Barany E, Bergdahl IA, Schütz A, Skerfving S, Oskarsson A. Inductively coupled plasma mass spectrometry for direct multielement analysis of diluted human blood and serum. J Anal Spectrom. 1997;12:1005-9, http://dx.doi.org/10.1039/a700904f.

19. Sandborgh-Englund G, Elinder CG, Langworth S, Schütz A, Ekstrand J. Mercury in biological fluids after amalgam removal. J Dent Res. 1998;77:615-24, http://dx.doi.org/10. 1177/00220345980770041501.

20. Bernard AM, Lauwerys RR. Significance of hyperferritinuria. Clin Chem. 1983;29(12):2121-2.

21. Duncan DB. Multiple range and multiple F tests. Biometrics. 1955;11:1-42, http://dx.doi.org/10.2307/3001478.

22. Dagnelie P. [Theories and statistic methods]. Agron Press Gemnloux. 1975;62(2):463. French.
23. Centers for Disease Control and Prevention. Preventing in lead poisoning in young children: A statement from the Centers for Disease control. Centers for Disease Control, Atlanta, GA [updated 1991 May 1; cited 1991 Jul 1]. Available from: http:/wonder.cdc.gov/wonder/prevguid/p0000029/ p0000029.asp\#head0010000000000001991,1-74S.

24. Lekouch N, Sedki A, Bouhouch S, Nejmeddine A, Pineau A, Pihan JC. Trace elements in children's hair, as related exposure in wastewater spreading field of Marrakesh (Morocco). Sci Total Environ. 1999;243(4):323-8.

25. Kamal A-AM, Eldamaty SE, Faris R. Blood lead level of Cairo traffic policeman. Sci Total Environ. 1991;105:165-70, http://dx.doi.org/10.1016/0048-9697(91)90339-G.

26. Abdel Rasoul GM, Al-Batanony MA, Mahrous OA, AboSalem ME, Gabr HM. Environmental lead exposure among primary school children in Shebin El-Kom District, Menoufiya Governorate, Egypt. Int J Occup Environ Med. 2012;3(4):186-94.

27. Mostafa GA, El-Shahawi HH, Mokhtar A. Blood lead levels in Egyptian children from high and low lead-polluted areas: Impact on cognitive function. Acta Neurol Scand. 2009;120(1):30-7, http://dx.doi.org/10.1111/j.16000404.2009.01155.x.

28. Hrubá F, Strömberg U, Černá M, Chen C, Harari F, Harari R, et al. Blood cadmium, mercury, and lead in children: An international comparison of cities in six European countries, and China, Ecuador, and Morocco. Environ Int. 2012;41:29-34, http://dx.doi.org/10.1016/j.envint.2011.12.001.

29. Stroh E, Lundh T, Oudin A, Skerfving S, Strömberg U. Geographical patterns in blood lead in relation to industrial emissions and traffic in Swedish children, 1978-2007. BMC Public Health. 2009;9:225, http://dx.doi.org/10.1186/14712458-9-225.

30. Health Canada. Report on Human Exposure to Environmental Chemicals in Canada 2010: Results of the Biomonitoring Component of the 2007-2009 Canadian Health Measures Survey, 2010 [updated 2010 March 10; cited 2010 Jul 10]. 
Available from: http://www.hc-sc.gc.ca/ewhsemt/pubs/contaminants/chms-ecms/section8.

31. Liangkai Z, Kusheng W, Yan L, Zongli Q, Dai H, Bao Z, et al. Blood lead and cadmium levels and relevant factors among children from an e-waste recycling town in China. Environ Res. 2008;108:15-20, http://dx.doi.org/10.1016/ j.envres.2008.04.002.

32. de Burbure C, Buchet JP, Bernard A, Leroyer A, Nisse C, Haguenoer JM, et al. Biomarkers of renal effects in children and adults with low environmental exposure to heavy metals. J Toxicol Environ Health A. 2003;66(9):783-98.

33. Leroyer A, Nisse C, Hemon D, Gruchociak A, Salomez JL, Haguenoer JM. Environmental lead exposure in a population of children in northern France: Factors affecting lead burden. Am J Ind Med. 2000;38:281-9, http:// dx.doi.org/10.1002/1097-0274(200009)38:3\%3C281::AIDAJIM6\%3E3.0.CO;2-Y.

34. Costa de Almeida GR, de Freitas Tavares CF, de Souza AM, Sampaio de Sousa T, Rodrigues Funayama CA, Barbosa Jr. F, et al. Whole blood, serum, and saliva lead concentrations in 6- to 8-year-old children. Sci Total Environ. 2010;408:1551-6, http://dx.doi.org/10.1016/j.scitotenv. 2009.12.034.

35. Ahamed M, Verma S, Kumar A, Siddiqui MK. Blood lead levels in children of Lucknow, India. Environ Toxicol. 2010;25:48-54.

36. Cousillas AZ, Manay N, Pereira L, Alvarez C, Coppes Z. Evaluation of lead exposure in Uruguayan children. Bull Environ Contam Toxicol. 2005;75:629-36, http:// dx.doi.org/10.1007/s00128-005-0799-4.

37. Schmidt CW. Lead in air. Adjusting to a new standard. Environ Health Perspect. 2010;118:76-9, http://dx.doi. org/10.1289/ehp.118-a76.

38. Mathee A, Röllin H, von Schirnding Y, Levin J, Naik I. Reductions in blood lead levels among school children following the introduction of unleaded petrol in South Africa. Environ Res. 2006;100(3):319-22, http://dx.doi.org/10.1016/ j.envres.2005.08.001.
39. Weyermann M, Brenner H. Alcohol consumption and smoking habits as determinants of blood lead levels in a national population sample from Germany. Arch Environ Health. 1997;52:233-9, http://dx.doi.org/10.1080/ 00039899709602892.

40. Nnorom IC, Osibanjo O, Oji-Nnorom CG. Cadmium determination in cigarettes available in Nigeria. Afr J Biotechnol. 2005;4(10):1128-32.

41. Lyngbye T, Jorgenson PJ, Grendjean P, Hansen ON. Validity and interpretation of blood lead levels: A study of Danish school children. Scand J Clin Lab Invest. 1990;50:441-9 [8;14:385-9], http://dx.doi.org/10.3109/00365519009091604.

42. Willers S, Schutz A, Attewell R, Skerfving S. Relation between lead and cadmium in blood and the involuntary smoking of children. Scand J Work Environ Health. 1998;14: 385-9, http://dx.doi.org/10.5271/sjweh.1905.

43. Needleman H. Lead poisoning. Ann Rev Med. 2004;55:20922,http://dx.doi.org/10.1146/annurev.med.55.091902.103653. 44. Safi J, Fischbein A, Haj S, Sansour R, Jaghabir M, Hashish MA, et al. Childhood lead exposure in the Palestinian authority, Israel, and Jordan: Results from the Middle Eastern regional cooperation project, 1996-2000. Environ Health Perspect. 2006;114:917-22.

45. Needleman HL, McFarland C, Ness RB, Fienberg SE, Tobin MJ. Bone lead levels in adjudicated delinquents. A case control study. Neurotoxicol Teratol. 2002;24:711-7, http:// dx.doi.org/10.1016/S0892-0362(02)00269-6.

46. Wright JP, Dietrich KN, Ris MD, Hornung RW, Wessel SD, Lanphear BP, et al. Association of prenatal and childhood blood lead concentrations with criminal arrests in early adulthood. PLoS Med. 2008;27:e101, http://dx.doi. org/10.1371/journal.pmed.0050101.

47. Landrigan P, Nordberg M, Lucchini R, Nordberg G, Grandjean P, Iregren A, et al. The declaration of Brescia on prevention of the neurotoxicity of metals. Am J Ind Med. 2007;50:709-11, http://dx.doi.org/10.1002/ajim.20404.

48. Lanphear BP, Dietrich K, Auinger P, Cox C. Cognitive deficits associated with blood lead concentrations 
below 10 microg/dl in US children and adolescents. Public Health Rep. 2000;115:521-9, http://dx.doi.org/10.1093/ $\mathrm{phr} / 115.6 .521$.

49. Chiodo LM, Jacobson SW, Jacobson JL. Neurodevelopmental effects of postnatal lead exposure at very low levels. Neurotoxicol Teratol. 2004;26:359-71, http://dx.doi. org/10.1016/j.ntt.2004.01.010.

50. Menke A, Muntner P, Batuman V, Silbergeld EK, Guallar E. Blood lead below 0.48 micromol/l (10 microg/dl) and mortality among US adults. Circulation. 2006;114(13):1388-94, http://dx.doi.org/10.1161/CIRCULATIONAHA.106.628321.

51. Staessen J. Low-level lead exposure, renal function and blood pressure. Verh K Acad Geneeskd Belg. 1995;57(6):527-74.

52. de Burbure C, Buchet JP, Leroyer A, Nisse C, Haguenoer JM, Mutti A, et al. Renal and neurologic effects of cadmium, lead, mercury, and arsenic in children: Evidence of early effects and multiple interactions at environmental exposure levels. Environ Health Perspect. 2006;114(4):584-90.

53. Yang H, Huo X, Yekeen TA, Zheng Q, Zheng M, Xu X. Effects of lead and cadmium exposure from electronic waste on child physical growth. Environ Sci Pollut Res. 2013;20(7):4441-7, http://dx.doi.org/10.1007/s11356012-1366-2.

54. Huseman CA, Varma MM, Angle CR. Neuroendocrine effects of toxic and low blood lead levels in children. Pediatrics. 1992;90:186-9.

55. Kim R, Hu H, Rotnitzky A, Bellinger D, Needleman H. A longitudinal study of chronic lead exposure and physical growth in Boston children. Environ Health Perspect. 1995; 103:952-7, http://dx.doi.org/10.1289/ehp.95103952.

56. Qi Q, Yang Y, Yao X, Ding L, Wang W, Liu Y, et al. Blood lead level of children in the urban areas in China. Chin J Epidemiol. 2002;23:162-6.

57. Huang DJ, Deng XP, Chen YJ. A study on the effects of preschool children's blood lead level on their height and weight. Guangdong Trace Elem Sci. 2005;12:25-7.

58. American Diabetes Association: Standards of medical care in diabetes (Position Statement). Diabetes Care.
2004;27 Suppl1:S15-35, http://dx.doi.org/10.2337/diacare.27. 2007.S15.

59. Hossny E, Mokhtar G, El-Awady M, Ali I, Morsy M, Dawood A. Environmental exposure of the pediatric age groups in Cairo City and its suburbs to cadmium pollution. Sci Total Environ. 2001;273(1-3):135-46, http://dx.doi.org/10. 1016/S0048-9697(00)00848-2.

60. Wong SL, Lye EJ. Lead, mercury and cadmium levels in Canadians. Health Rep. 2008;19(4):31-6.

61. Batáriová A, Spěváčková V, Beneš B, Čejchanová M, Šmíd J, Černá $\mathrm{M}$. Blood and urine levels of $\mathrm{Pb}, \mathrm{Cd}$ and $\mathrm{Hg}$ in the general population of the Czech Republic and proposed reference values. Int J Hyg Environ Health. 2006;209:359-66, http://dx.doi.org/10.1016/j.jijheh.2006.02.005.

62. Beneš B, Spěváčková V, Šmíd J, Čejchanová M, Černá M, Šubrt P, et al. The concentration levels of $\mathrm{Cd}, \mathrm{Pb}, \mathrm{Hg}, \mathrm{Cu}$, $\mathrm{Zn}$ and Se in blood of the population in the Czech Republic. Cent Eur J Public Health. 2000;8:117-9.

63. Link B, Gabrio T, Piechotowski I, Zollner I, Schwenk M. Baden-Wuerttemberg Environmental Health Survey (BWEHS) from 1996 to 2003: Toxic metals in blood and urine of children. Int J Hyg Environ Health. 2007;210:357-71, http:// dx.doi.org/10.1016/j.ijheh.2007.01.031.

64. Skerfving S, Bencko V, Vahter M, Schütz A, Gerhardsson L. Environmental health in the Baltic region - toxic metals. Scand J Work Environ Health. 1999;25 Suppl 3:40-64.

65. Khassouania CE, Soulaymania R, Maurasb Y, Allainb P. Blood cadmium concentration in the population of the Rabat area, Morocco. Clin Chim Acta. 2000;302:155-60, http://dx.doi.org/10.1016/S0009-8981(00)00368-5.

66. Sirivarasai J, Kaojaren S, Wananukul W, Srisomerang P. Non-occupational determinants of cadmium and lead in blood and urine among a general population in Thailand. Southeast Asian J Trop Med Public Health. 2002;33:180-7.

67. Shin J-Y, Lim J-H, Park S-G, Lee J-N, Jang M, Huh C-S, et al. Influence of smoking on blood cadmium concentration in University students. J Prev Med Public Health. 2004;37: 225-31. 
68. Alvarez Leite EM, Leroyer A, Nisse C, Haguenoer JM, de Burbure CY, Buchet JP, et al. Urinary homovanillic acid and serum prolactin levels in children with low environmental exposure to lead. Biomarkers. 2002;7:49-57, http://dx.doi. org/10.1080/135475001100744192.

69. Shaham J, Meltzer A, Ashkenazi R, Riban J. Biological monitoring of exposure to cadmium, a human carcinogen, as a result of active and passive smoking. J Occup Environ Med. 1996;38:1220-8, http://dx.doi.org/10.1097/00043764199612000-00007.

70. Alfven T, Jarup L, Elinder C-G. Cadmium and lead in blood in relation to low bone mineral density and tubular proteinuria. Environ Health Perspect. 2002;110:699-702, http:// dx.doi.org/10.1289/ehp.02110699.

71. Jin T, Nordberg M, Frech W, Dumont X, Bernard A, Ye TT, et al. Cadmium biomonitoring and renal dysfunction among a population environmentally exposed to cadmium from smelting in China (ChinaCad). Biometals. 2002;15:397-410, http://dx.doi.org/10.1023/A:1020229923095.

72. Satarug S, Haswell-Elkins MR, Moore MR. Safe levels of cadmium intake to prevent renal toxicity in human subjects. Br J Nutr. 2000;84:791-802.
73. Järup L, Hellström L, Alfvén T, Carlsson MD, Grubb A, Persson B, et al. Low level exposure to cadmium and early kidney damage: The OSCAR study. Occup Environ Med. 2000;57: 668-72, http://dx.doi.org/10.1136/oem.57.10.668.

74. Cikrt M, Tichý M, Bláha K, Bittnerová D, Havrdová J, Lepsi P, et al. The study of exposure to cadmium in the general population. II. Morbidity studies. Pol J Occup Med Environ Health. 1992;5(4):345-56.

75. El-baz F, Elhossiny RM, Elsayed AB, Gaber GM. Hair mercury measurement in Egyptian autistic children. Egypt J Med Hum Genet. 2010;11:135-41, http://dx.doi.org/10. 1016/j.ejmhg.2010.10.007.

76. Caldwell KL, Mortensen ME, Jones RL, Caudill SP, Osterloh JD. Total blood mercury concentrations in the U.S. population 1999-2006. Int J Hyg Environ Health. 2009;212: 588-98, http://dx.doi.org/10.1016/j.ijheh.2009.04.004.

77. World Health Organisation. Health risks of heavy metals from long-range transboundary air pollution. Joint $\mathrm{WHO} /$ Convention Task Force on the Health Aspects of Air Pollution. Europe: WHO; 2009.

78. Campbell C, Osterhoudt KC. Prevention of childhood lead poisoning. Curr Opin Pediatr. 2000;12:428-37.

This work is available in Open Access model and licensed under a Creative Commons Attribution-NonCommercial 3.0 Poland License - http://creativecommons.org/ licenses/by-nc/3.0/pl/deed.en. 